\title{
Author Correction: Sequential transfection of RUNX2/SP7 and ATF4 coated onto dexamethasone- loaded nanospheres enhances osteogenesis
}

\author{
Hye Jin Kim, Ji Sun Park, Se Won Yi, Hyun Jyung Oh, Jae-Hwan Kim \& Keun-Hong Park
}

Correction to: Scientific Reports https://doi.org/10.1038/s41598-018-19824-x, published online 23 January 2017

The original version of this Article contained an error in the title of the paper, where "nanospheres enhances" was incorrectly given as "nanospheresenhances".

In addition, this Article contained an error in the Acknowledgements section,

“and the Next-Generation BioGreen 21 Program (No.PJ000000), Rural Development Administration, Republic of Korea."

now reads:

"and the Next-Generation BioGreen 21 Program (No.PJ01122202), Rural Development Administration, Republic of Korea."

These errors have now been corrected in the PDF and HTML versions of the Article.

(i) Open Access This article is licensed under a Creative Commons Attribution 4.0 International (c) License, which permits use, sharing, adaptation, distribution and reproduction in any medium or format, as long as you give appropriate credit to the original author(s) and the source, provide a link to the Creative Commons license, and indicate if changes were made. The images or other third party material in this article are included in the article's Creative Commons license, unless indicated otherwise in a credit line to the material. If material is not included in the article's Creative Commons license and your intended use is not permitted by statutory regulation or exceeds the permitted use, you will need to obtain permission directly from the copyright holder. To view a copy of this license, visit http://creativecommons.org/licenses/by/4.0/.

(C) The Author(s) 2019

Department of Biomedical Science, College of Life Science, CHA University, 6F, CHA Biocomplex, 689 Sampyeongdong Bundang-gu, Seongnam-si, 134-88, Korea. Correspondence and requests for materials should be addressed to J.-H.K. (email: jaehwan_k@cha.ac.kr) or K.-H.P. (email: pkh0410@cha.ac.kr) 